\title{
VESTLUSKAVATSUSED HINGAMISMUSTRIS
}

\author{
KÄTLIN AARE
}

A rtikkel on mõeldud ülevaatena kõnehingamisest kui uurimisobjektist ning uurimistööst, mis kõnehingamise vallas eestikeelset andmestikku kasutades seni läbi viidud on. Lähemalt kirjeldatakse artiklis, kuidas eristub kõnehingamine organismi üldise gaasivahetuse eesmärgil toimuvast hingamisest, kuidas ja miks erinevad spontaanse ja loetud kõnega kaasnevad hingamismustrid, ning uuritakse, kuidas hingamine mõjutab argivestlusi.

Kõneplaneerimise lihtsustatud mudeli järgi muutub mõte kõneks sammhaaval ning vastab lõppstaadiumis nõuetele, mille määrab konkreetne suhtlussituatsioon. Kõneplaneerimist võib mõõta näiteks aju elektrilise aktiivsuse ja reaktsiooniaegade põhjal, ent ühtlasi peegeldub see näiteks hingamismustrites. Eriti selgelt on kõneplaneerimine vaadeldav loetud kõnega kaasnevates hingamismustrites. Spontaansele kõnele rakendub kognitiivne lisasurve, sest kuskilt maha lugeda pole võimalik ning kõnet tuleb samaaegselt planeerida. Seetõttu on spontaanses kõnes artikuleerimiseni jõudmise protsess keerulisem ja hingamismustrid ebakorrapärasemad. Sellest hoolimata on senised kõnehingamist käsitlevad uurimused näidanud, et spontaansele kõnele iseloomulikust hingamismustrist võib leida süstemaatiliselt esinevaid mehhanisme vooruvahetuse reguleerimiseks vestlustes (nt Schegloff 1996; French, Local 1983; Edlund jt 2014).

Artikli fookus on kahel kõneplaneerimise seisukohalt erineval uurimisobjektil. Esiteks keskendutakse sellisele objektile, mida ei ole võimalik ette planeerida: tagasisidepartiklite (nt $m h m h$, jajah, okei) ajastus hingamistsüklis. Teiseks on vaatluse all vooruvahetust reguleerivad vahendid, mida võib leida hingamismustritest ja mida üldjuhul planeeritakse vestluses ette. Eesmärk on välja selgitada, kuidas nende kõneüksuste erinev planeerimine väljendub kõnehingamises, eriti kõneüksustele vahetult eelnevate hingetõmmete ulatuses ja kõneüksuste ajastamises hingamisfaaside suhtes. Tulemused põhinevad kahe ja kolme osalejaga spontaansetel eestikeelsetel vestlustel, mis on salvestatud 2014. ja 2015. aastal Stockholmi ülikooli foneetika laboris. Tulemusi on varem osaliselt käsitletud artiklites Aare jt (2014) ning Aare jt (2015).

\section{Kõnehingamine}

Kõnehingamine tähendab hingamisorganite kasutusviisi, millega tagatakse hääle tekitamiseks vajalik õhuvoog. Kõnehingamine nõuab rohkem pingutust kui vaikne hingamine ning rääkimise ajal kontrollib sisse- ja väljahingamiste sagedust ja ulatust aju kõnekeskus. See eristab kõnehingamist tavalisest, metaboolsest hingamisest kõige enam: metaboolset hingamist kontrollib ajutüvi, aga kõnehingamist reguleeritakse ajukoores (Euler 1982; McKay jt 2003). Nimetatud erinevuse tähtsus seisneb selles, et ajukoor on närvi- 
süsteemi kõrgeim tasand ning seal toimub kõrgem närvitalitlus kui ajutüves, mis kontrollib peamiselt eluks vajalike funktsioonide tööd (sh näiteks südame löögisagedust).

Kõnelemise ajal kasutatakse õhu liigutamiseks nii rindkeret kui ka alakõhtu. Mõnel kõnelejal võib domineerida neist üks, mõnel töötavad need võrdselt (Hixon 1982: 82). Kõnelejate individuaalsed harjumused, ent ka hääle kvaliteet, valjus ja artikuleeritava sõnumi foneetiline koostis (nt takistuse ulatus suuõones helilisi või helituid häälikuid produtseerides) mõjutavad seda, kui suurt pingutust hingamisaparatuurilt nõutakse (Clark jt 2007: 172-173).

Kui parasjagu ei räägita, on tegemist vaikse hingamisega. Vaiksel hingamisel korduvad sisse- ja väljahingamistsüklid minutis umbes 12 korda ning sisse- ja väljahingamisfaasid on üsna võrdse kestusega. Kõnelemise ajal vahelduvad faasid harvem, sisse hingatakse kiiresti ja välja väga aeglaselt (vt joonist 1).

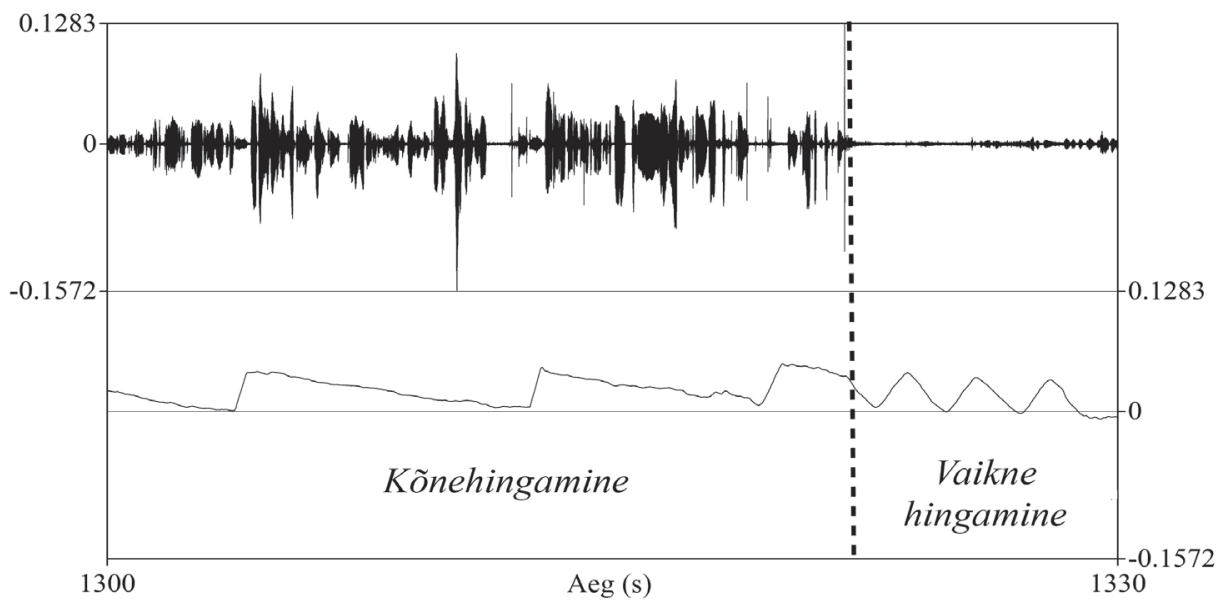

J o o n is 1. Näide hingamismustritest. Katkend on pärit 2014. aasta kevadel salvestatud eestikeelsest materjalist. Ülemine signaal on kõne helilaine, alumine signaal on hingamislaine.

Faaside suhtelised kestused muutuvad kõnehingamise ajal, sest oluliselt lühemate hingetõmmetega vähendatakse katkestuste osakaalu kõnevoos. Välja hingatakse seevastu kauem, sest hingamisteede ülemises osas takistab kõneaparaadi osade liikumine (nt keele asend, suu avatus) artikuleerimise ajal õhu vaba väljavoolu (Hixon 1987: 45-46).

Kõnehingamise uurimisel on kasutatud prosoodilise üksuse mõistet, mida eesti keeles võiks nimetada hingetõmberühmaks (ingl breath group). Hingetõmmete asukohtade uurimise tulemusel on selgunud, et kõne jagatakse hingetõmberühmadeks mitte üksnes õhuvajadusi arvestades, vaid ka grammatilise struktuuri järgi. Seetõttu koosnevad hingetõmberühmad üldjuhul üsna terviklikest lausetest, osalausetest, fraasidest vm. Hingetõmberühma mõiste loodigi selleks, et tähistada prosoodilist rütmi, mille ühe üksuse piiridesse jääb liht- või väitlause tavalises kõnes (Lieberman 1967: 2). Ühes 
hingetõmberühmas on järelikult ühe väljahingamisfaasi jooksul öeldu, selles sisalduvad mõttepausid, naer ja kõik muu, mis mahub kahe sissehingamisfaasi vahele. Joonisel 1 on kõnehingamise ajal vaadeldavad kolm tervet ja üks poolik hingetõmberühm, kus üksuse algust märgib hingamislainel amplituudi järsk tõus ja selle lõppu langemine lähtenivoole.

\section{Kõneplaneerimine}

Kuigi üldiselt ollakse ühel nõul, et kõneplaneerimine toimub inkrementaalselt ehk sammhaaval, ei ole siiski teada, milliseid samme see protsess täpselt hõlmab. Mõned uurijad arvavad, et tegemist on radikaalse inkrementaalsusega (nt Wheeldon, Lahiri 1997; Levelt 1989), mis tähendab, et korraga planeeritakse ette ühte rangelt määratud osa kõnest. Näiteks saab kõne artikuleerimine selle teooria kohaselt alata alles siis, kui kõneleja teab eeloleva lausungi esimest fonoloogilist sõna; selle väljaütlemise ajal peaks toimuma järgmise fonoloogilise sõna planeerimine. Teine grupp uurijaid arvab, et kõnet planeeritakse paindlikumalt ja otsitakse tasakaalu planeerimisele kuluva aja ning lausungi võimalikult kiire alustamise vahel. On leitud tõendeid, et ette võib planeerida fonoloogilisest sõnast suuremaid üksusi (Ferreira, Swets 2002: 76-80). Näiteks võib tuua väljendite kasutamise: vanasõnad, kollokatsioonid ja idioomid ei ole kõneleja töömälus üksikutest sõnadest koosnevad jadad, vaid moodustavad ühe tervikliku üksuse (nt Wray, Perkins 2000). Seega võib planeerimine toimuda ka nii, et kõigepealt keskendutakse suuremale ideele või mõnele loole, mida seejärel väiksemate üksustega sammhaaval täitma hakatakse, kuni eesmärk on saavutatud.

Kõneplaneerimist ja üksusteks organiseerimist on palju uuritud, eriti võrreldes kõne ja pauside ajastust ning proportsioone. Kõnes esinevaid pause mõjutavad näiteks kõnetempo, süntaktiliste piiride tugevus, tunderõhk, lause/ lausungi pikkus jne. On väidetud, et pausid esinevad suuremate struktuuriüksuste piiril, enne pikki ja keerulise konstruktsiooniga sõnu või näiteks pärast intonatsioonirühma esimest sõna (Cruttenden 1986: 30-31). Pauside asukohti ja kõrgemate fonoloogiliste üksuste piire võrreldes on leitud, et kõnelejad planeerivad ette lauseid ja osalauseid, ent on võimelised planeerima veelgi kõrgemaid üksusi, mis koosnevad mitmest lausest ja moodustavad suurema semantilise terviku (Butterworth 1975: 84). Samuti näitavad uurimistulemused, et kuigi kõnet võib planeerida ette rohkem kui vaid esimese fraasi ulatuses, sõltub planeerimise ulatus siiski kõnelejast (Krivokapić 2010: 3). Pause kasutatakse vestlustes ka kommunikatiivsetel põhjustel: kui kõneleja ajastab pausid suuremate struktuuriüksuste piirile, saab ta sellega aidata vestluspartneril kõnet lihtsamini ja kiiremini mõista (Butterworth 1975: 84).

\subsection{Kõneplaneerimine loetud kõnes}

Kõneplaneerimise kohta uute teadmiste saamiseks on lähemalt uuritud peamiselt loetud kõne hingamismustreid ja hingamisega seotud muutujaid. Ette loetud saksakeelseid tekste uurides on selgunud, et $100 \%$ hingetõmmetest toimuvad süntaktilisel piiril, mis on märgitud interpunktsiooni või sidesõnaga (Rochet-Capellan, Fuchs 2013: 1128). Veelgi täpsemalt, loetud kõnes võetakse 
uus hingetõmme alati enne uue lõigu algust, väga suure tõenäosusega lausete vahel ja mõnikord ka liitlause osalausete piiril (Conrad jt 1983: 224). Märkimisväärne on fakt, et isegi sellistes lugemiskatsetes, kus katseisikutel palutakse teksti lugeda vaikselt oma peas, muutub lugeja hingamismuster pigem kõnelemist iseloomustava mustri sarnaseks (Conrad, Schönle 1979: 266), mille puhul hingatakse sisse kiiresti ja välja väga aeglaselt.

Saksa keele põhjal on leitud hulk teksti süntaktilise ülesehitusega seotud hingamismustreid (Fuchs jt 2013). Näiteks on avastatud, et pikemad ja sügavamad hingetõmbed eelnevad pikematele lausetele, ent mitte tingimata süntaktiliselt keerukama ehitusega lausetele. Komplekssemate lausetega kaasneb selle kompenseerimiseks aga suurem arv hingetõmbeid lause sees (Fuchs jt 2013: 38). Whaleni ja Kinsella-Shaw' uurimistulemused inglise keele kohta näitavad samuti, et hingetõmbe kestus on seda pikem, mida pikem on järgnev lause (nii ajaliselt kui ka silbiliselt), olenemata sellest, kas hingetõmbe kestust mõõdeti akustiliselt või füsioloogiliselt (Whalen, Kinsella-Shaw 1997: 145-146).

Grosjean ja Collins seevastu uurisid kõnetempo ja hingamispauside asukoha seoseid. Selgus, et aeglaselt ja normaalse tempoga kõneledes hingatakse tõepoolest sisse suuremate struktuuriüksuste piiril, aga tempo kiirenedes on hingetõmbeid märksa vähem ning neid võetakse vaid siis, kui kopsudes olevast õhust jätkamiseks ei piisa. Selliselgi juhul on hingetõmbed väga lühikese kestusega. Järelikult kiirendatakse kõnetempot osaliselt hingamispauside hulga ja kestuse arvelt. (Grosjean, Collins 1979: 104-107) Sarnasele käitumisele viitab Hixoni jt eksperiment, mille käigus katseisikutel paluti lugeda pikki lauseid väga väikese kopsudes oleva õhu hulgaga. Katse tulemused näitavad, et kui kõnelejal on kopsudes vähe õhku, muutuvad hingamise mehaanilised aspektid olulisemaks kui vajadus kõne fraasideks jaotamise järele. Väike õhuhulk sundis katseisikuid sisse hingama grammatiliselt ebasobivates kohtades, et jätkamine võimalik oleks. (Hixon jt 1973: 107)

\subsection{Kõneplaneerimine spontaanses kõnes}

Spontaanses kõnes pole kõnelejatel võimalust teksti kuskilt maha lugeda ning seetõttu ei saa rääkijad spontaanset kõnet nii mugavalt ja kiiresti ette planeerida ega uurijad kõnet ning sellega seotud hingamismustreid nii täpselt ennustada. Seni pole spontaanse kõnega seotud hingamismustreid uuritud nii palju kui loetud kõnega kaasnevaid, ent nende vähesest uurimisest on siiski saadud olulisi tulemusi.

Inglise keele põhjal on leitud, et hingetõmmete asukohad spontaanses kõnes järgivad võrreldes loetud kõnega lausungite süntaktilist struktuuri vähem, umbes $72 \%$ ulatuses (Winkworth jt 1995: 132-139). Võrdlevalt on inglise spontaankõnes hingetõmbed umbes $13 \%$ ulatuses mittegrammatilistes kohtades (vrd $2 \%$ loetud kõnes) (Wang jt 2010: 300). See vahe on tõenäoliselt seotud kognitiivse lisasurvega, mis parasjagu käimasolevale spontaansele kõnele omane on. Reaalajas planeerimine on koormavam ülesanne kui teksti paberilt lugemine, ent sellegipoolest näitavad mõlemad esiletoodud uurimistulemused, et kõneplaneerimine on ka spontaanses kõnes väga organiseeritud. Winkworthi ja tema kaasautorite väitel on lisaks tähtsad individuaalsed erinevused, sest spontaanses kõnes peegeldab hingetõmberühm grammatiliste 
üksuste asemel pigem semantilisi; nende uurimusest selgus samuti ootuspäraselt, et pikemad hingetõmberühmad algavad märgatavalt kõrgema kopsude õhutasemega kui lühemad (Winkworth jt 1995: 139-140).

Saksa keele spontaankõnest on otsitud hingetõmmete sügavuse ja kestuse seoseid hingetõmberühmade süntaktilise sisuga. Nende tulemuste järgi sõltuvad nii hingetõmbe amplituud kui ka kestus järgneva hingetõmberühma ajalisest kestusest, ent olulist rolli mängib ka lausungit alustava osalause tüüp. Kui lausung algab pealausega, on eelnev hingetõmme sügavam. Lisaks leiti, et hingetõmbed olid sügavamad, kui hingetõmberühm sisaldas vähemalt ühte kõhkluspausi. (Rochet-Capellan, Fuchs 2013: 1130-1131)

\section{Vooruvahetussüsteemi mõjutavad hingamismustrid}

Spontaansetes vestlustes on kõne ja hingamismustrite ebakorrapärasus veelgi rõhutatum. Ka vooruvahetussüsteem, mis vestluste kulgemise määrab, on seetõttu keeruline.

Jaffe ja Feldsteini (1970: 19) järgi defineeritakse vestlust kui kahe või enama omavahel suhtluses oleva kõneleja häälesolekute ja vaikuste jada. Vestlusrütmi iseloomustab selle võnkuv muster - korraga on vaid ühel kõnelejal kõnevoor ning samaaegset rääkimist välditakse (Jaffe, Feldstein 1970: 3). Feldstein on kõnevooru defineerinud kui lausungit, mis koosneb ühe kõneleja häälesolekust ja pausidest ning on piiritletud vahetuspausidega, kus ühe kõneleja kõnevoor vahetub mõne teise vestluspartneri rääkimiskorraga. Sellise sujuva vahetuspausi puudumise korral on kõnevooru piirid mis tahes kohas, kus keegi teine rääkima hakkab ja ise kõnevooru haarab. (Feldstein 1973: 95) Vestlus on igal juhul partnerite koostöö tulemus: vooruvahetust reguleerivate vahendite abil määratakse nii osalejate rollid kui ka kõnevoorude alustamiseks ja lõpetamiseks sobivad hetked (McFarland 2001: 128).

Vooruvahetuse reguleerimiseks kasutatakse erinevaid strateegiaid, ehkki vestluspartnerid ei pruugi nende kasutamist teadlikult märgata, tajudes signaale pigem alateadlikult. On vahendeid, millega saavutatakse kõnevooru alustamise õigus, ent ka selliseid vahendeid, millega näidatakse, et voor pole veel lõppenud, või vastupidi, sai just läbi. Et need signaalid oma eesmärgi saavutaksid, peavad need olema piisavalt teadvustatavad ja üheselt mõistetavad (Gumperz 1982: 159). Sündmused vooruvahetussüsteemis, nagu kõnelejate vahetus, kus üks kõneleja kaotab kõnevooru ja teine selle haarab, on mõjutatavad näiteks intonatsiooni, rõhu, intensiivsuse ja hääle kvaliteedi, pauside ja kõnerütmi ning muude kõne- ja hääleomaduste varieerimise abil. Nende kasutamine sõltub paljuski sellest, mida vestluses osaleja püüab saavutada, kuid oma rolli mängib ka inkrementaalsus, sest lausungi prosoodilist sisu kujundatakse sammhaaval vastavalt sellele, kas ja kuidas vestlus jätkuda võiks (Couper-Kuhlen, Selting 1996: 29-30).

On väidetud, et vooruvahetusmehhanisme võib leida ka hingamismustritest. Näiteks on sissehingamisi peetud selgeks kõne alustamise märgiks (Schegloff 1996: 92-93). Enne kõnelemise alustamist tõmmatakse tavaliselt kopsud õhku täis ning selle tulemusel rindkere venib, mis reedab füüsilise signaalina potentsiaalse kavatsuse alustada kõnevooru. Suure kõnelejate grupi hingetõmmete sügavusi võrreldes on leitud, et hingetõmbed on kõne- 
vooru alustajatel sügavamad kui neil, kes parasjagu ei alusta vooru ja satuvad kuulaja rolli (Ishii jt 2014: 23). Samuti on leitud, et vooru alustamise katsed on edukamad, kui nendele eelneb (kuuldav ja/või füüsiliselt märgatav) hingetõmme (Rochet-Capellan, Fuchs 2014: 12-13).

\section{Eksperimendid}

Artikli sissejuhatuses tõstatatud uurimisküsimustele vastuste leidmiseks salvestati Stockholmi ülikooli foneetikalaboris 2014. ja 2015. aastal hulk eestikeelseid spontaanseid vestlusi. Ehkki ühe eksperimendi jaoks kasutati dialooge ja teise jaoks kolme osalisega vestlusi, on ülejäänud salvestuspõhimõtted ja katsete tehniline ülesehitus samasugune.

Katsete käigus salvestati umbes 20-minutilisi spontaanseid eestikeelseid vestlusi. Osalejad olid vabatahtlikud, 20-35-aastased (kahe katse osalejate keskmine vanus salvestushetkel oli 25 a) ning keskmise kehamassiindeksiga 21,9. Vanus on oluline parameeter katseisikute valimisel, sest vananemisega väheneb kopsude elastsus, tagasitõmbumisvõime ning sisse- ja väljahingamisel olulist rolli mängivate lihaste jõud (Huber 2008: 323). Kehamassiindeksi väärtus ${ }^{1}$ on oluline, sest normist suurema väärtuse korral väheneb nii maksimaalne õhuhulk, mida inimene on võimeline kopsude puhkeasendist välja hingama, kui ka puhkeasendi kopsumaht üldiselt. ${ }^{2}$ Seda põhjustab ülekaalu mõju rindkere mehaanikale (Jones, Nzekwu 2006: 830).

Kõnelejad ei toonud esile kõne-, keele-, kuulmis-, hingamis- ega muid häireid, mis nende hingamist või vestlemist mõjutada oleksid võinud. Kõikide katsetes osalejate emakeel oli eesti keel. Ükski katseisik polnud suitsetaja ning kõik olid salvestuse toimumise ajal terved. Salvestussessioonil osalejad tundsid üksteist hästi, peamiselt kirjeldati oma suhteid sõprusena. Suurem osa katseisikuid reisis salvestuse jaoks Eestist Stockholmi, ent ühel katsel osalesid Stockholmis elavad eestlased. Salvestustel osalejad ei teadnud enne katse algust salvestuste täpset eesmärki ning neile ei antud ühtki suunist võimalike vestlusteemade kohta.

Vestlused salvestati samaaegselt nii helis kui ka videos. Lisaks sellele oli iga osaleja ülakeha ümber asetatud kaks spetsiaalset elastset rihma (Ambu RIP-mate), mis mõõtsid ja salvestasid muutusi kõneleja rindkere ümbermõõdus LabChart tarkvaraga (ADInstruments). Kahe rihma signaalid kombineeriti kaalutud summaks (Respiratory Inductance Plethysmography, Watson 1980), mis näitab laine kujul sisse- ja väljahingamisfaaside sügavuse ja kestuse muutumisi ajas paralleelselt helilainega (nagu näha joonisel 1). Signaali täpsuse huvides paluti katseisikutel kanda õhukesi liibuvaid riideid.

Salvestussessioonile eelnes rihmade kalibreerimine. Üks rihm mõõtis kehaümbermõõdu muutusi rinnaku ülaosalt ning teine alakõhu ümbert. Et

\footnotetext{
${ }^{1}$ Kehamassiindeksi väärtus arvutatakse järgmise valemiga: KMI = mass (kg) / (pikkus $(\mathrm{m}))^{2}$ ehk kehakaal jagatud pikkuse ruuduga.

${ }^{2}$ Inimene on võimeline välja hingama umbes $80 \%$ kopsudesse mahtuvast õhust, ülejäänud $20 \%$ on alati kopsudes olemas. Niisiis erineb kopsude üldine mahutavus puhkeasendis sellest õhuhulgast, mida samalt tasemelt päriselt välja suudetakse hingata. Kopsude puhkeasendiks loetakse seda hetke, mille kopsud saavutavad kerge ohke lõpus, kui ükski sise- ega välisjõud neile ei avaldu. Sel hetkel on kopsudes õhku umbes $40 \%$ kasutatavast kopsumahust.
} 
need signaalid oleksid tasakaalus, tuli katseisikutel kõigepealt sooritada võrdmahu katse (ingl isovolume maneuvre; Konno, Mead 1967): hingata sisse mõõdukas hulk õhku, mida liigutatakse hinge kinni hoides alakõhu lihaste kokkusurumise abil rinnaku ülaossa ja lihaste lõdvaks laskmise abil tagasi alaossa. Nii leiti iga katseisiku jaoks rihmadevaheline tasakaalupunkt, mis fikseeriti Stockholmi ülikoolis välja töötatud spetsiaalse protsessoriga (RespTrack). Peale selle paluti katseisikutel hingata võimalikult palju õhku sisse ja võimalikult palju välja, et hiljem nende maksimum- ja miinimumväärtuste abil iga kõneleja hingamissignaalist mõõdetud väärtused normaliseerida suhtarvuna kopsumahust.

Salvestuse ajal seisid kõnelejad ümber 1 meetri kõrguse ümmarguse laua, millel oli iga kõneleja poole suunatud eraldi lainurkkaamera (mudel GoPro Hero 3+ Silver). Nii rihmade kalibreerimise kui ka vestluse vältel paluti katseisikutel olla võimalikult liikumatult, hoides käsi pidevalt laua peal, et vähendada žestide jm järskude liigutuste mõju salvestatavale hingamissignaalile. Kuna rihmad salvestavad muutusi kehaümbermõõdus, jäävad kogutud andmestikku ka kõik suuremad liigutused. Videosalvestuste abil saab sellised anomaalsed juhtumid signaalist üles leida ja andmestikust välja jätta.

Andmed segmenditi poolautomaatselt, kasutades programmi Praat (Boersma, Weenink 2015) ja programmeerimiskeeles Python loodud skripte (Buschmeier, Włodarczak 2013). Hingamissignaalide summa jagati sisse- ja väljahingamisfaasideks. Vähesel määral liigutati käsitsi eelnevalt skriptidega määratud segmendipiire, samuti lisati piire, kui automaatne süsteem oli need märkimata jätnud. Andmestikus märgiti ära ka vestluses osalejate tagasisidepartiklid, naermised, köhatused jm.

\subsection{Eksperiment 1. Tagasisidepartiklid hingamismustris}

Tagasisidepartiklid (ingl backchannels, Yngve 1970), nt $m h m h$, ahah, on tüüpiliselt lühikesed ühe- või kahesilbilised vastused, millega kuulaja reageerib kõneleja esitatud informatsioonile (Gardner 2001) ning on mõeldud märguandena, et ta mõistab ja jälgib partneri juttu, soovimata haarata kõnevooru (nt Heldner jt 2013). Tagasisidepartiklite lühiduse ja suhtelise vaiksuse tõttu on põhjust arvata, et nende planeerimine erineb muude lausungite planeerimisest ning see kajastub ka hingamismustris, esinedes nt sissehingamisfaasi jooksul. Sellest ajendatuna oli eksperimendi eesmärk välja selgitada, kuidas jaotuvad tagasisidepartiklite asukohad hingamismustris võrreldes muude lausungitega.

Eksperimendis kasutati dialoogidest kogutud andmeid. Helisignaal jagati käsitsi pausideks, lausungiteks ja tagasisidepartikliteks. Tagasisidepartiklite määramisel jälgiti, et need piirneksid mõlemalt poolt vähemalt $500 \mathrm{~ms}$ pikkuse pausiga. Lühem paus võib suurema tõenäosusega tähendada, et tagasisidepartikkel on seotud eelnenud kõneüksusega või et kuulajal on soov pärast selle ütlemist haarata kõnevoor. Pärast hingamisfaaside ja kõneüksuste algus- ning lõpuaegade väljaselgitamist normaliseeriti kõne algusajad vastavalt hingamisfaasile, millega need kokku sattusid: 1) kõneüksuse algus produtseerija väljahingamisfaasis, 2) kõneüksuse algus vestluspartneri sisse- või väljahingamisfaasis. 
Analüüs põhineb 277 tagasisidepartiklil ja 732 lausungil. Väike arv tagasisidepartikleid eemaldati analüüsi esimesest osast, sest need toimusid sissehingamisfaasi jooksul (1) või vältasid üle mitme hingamisfaasi (4). Viimasel juhul on tõenäoliselt tegu mõõtmistulemuste ebatäpsusega. Kogutud tagasisidepartiklid olid enamasti nõusolekut väljendavad ( $m h m h, a h a h, j a j a h, o k e i)$, aga esines ka üllatust väljendavaid partikleid (tegelt, $a h$ ).

Analüüsi esimeses osas keskenduti tagasisidepartiklite ja lausungite esinemisele väljahingamisfaasis. Ootuspäraselt selgus, et pikemad lausungid algavad kõige sagedamini (44\%) vahetult pärast hingetõmbe lõppu väljahingamisfaasi alguses (vt joonist 2). Tagasisidepartiklitest algas $27 \%$ väljahingamisfaasi esimeses kümnendikus, teine tavapärane tagasisidepartiklite algus asub väljahingamisfaasi teises pooles. Lisaks võib jooniselt 2 näha, et tagasisidepartiklite alguspunktid on hingamistsüklis võrdsemalt jaotunud kui pikemate lausungite algused.
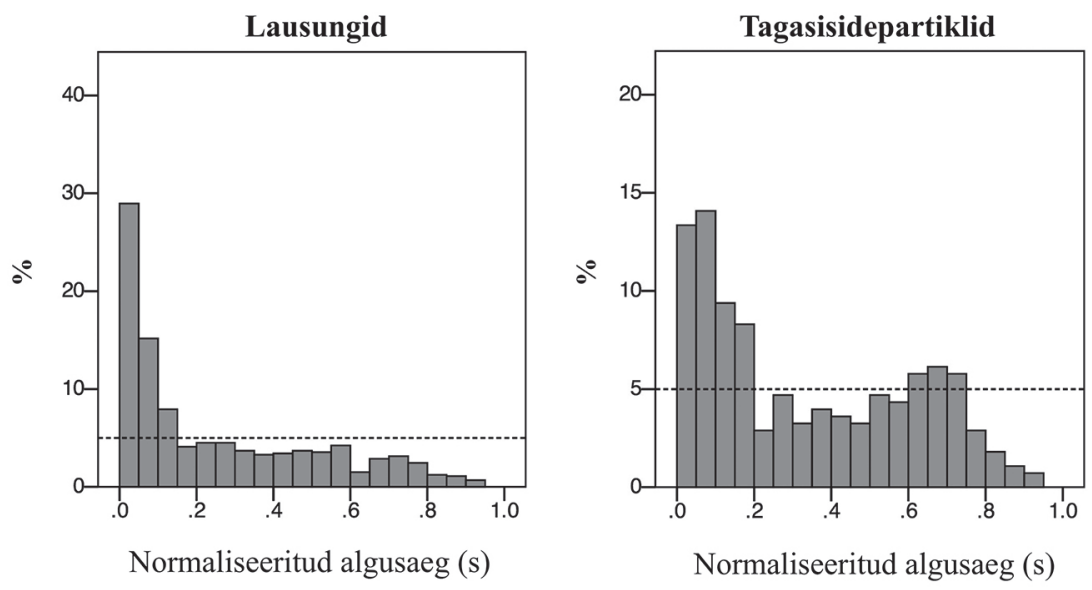

J o o n is 2. Lausungite ja tagasisidepartiklite normaliseeritud algusaegade jaotumine väljahingamisfaasis.

Et välja selgitada, kas sellist jaotust põhjustab tagasisidepartiklite funktsioon või lühike kestus, jagati kogu andmestik kestuse järgi kaheks. $99 \%$ tagasisidepartiklitest olid lühemad kui $800 \mathrm{~ms}$, seetõttu jagati andmestik lühikesteks (<800 ms) ja pikkadeks (> $800 \mathrm{~ms}$ ) lausungiteks. Joonisel 3 on näha, et pikemad lausungid käituvad samamoodi nagu lausungid joonisel 2: peaaegu pooled algasid väljahingamisfaasi esimeses kümnendikus ning hiljem alustati järjest vähem lausungeid. Lühemad lausungid algavad sarnaselt tagasisidepartiklitega enamasti üsna väljahingamisfaasi alguses või siis, kui väljahingamisfaas on 70-80\% ulatuses juba läbi. 


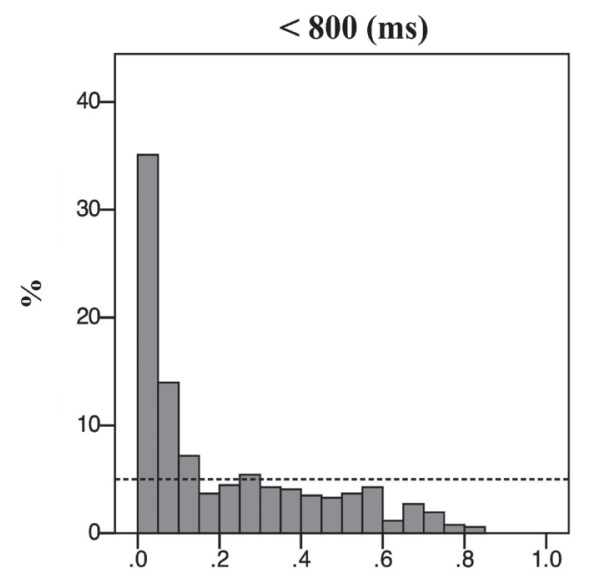

Normaliseeritud algusaeg (s)

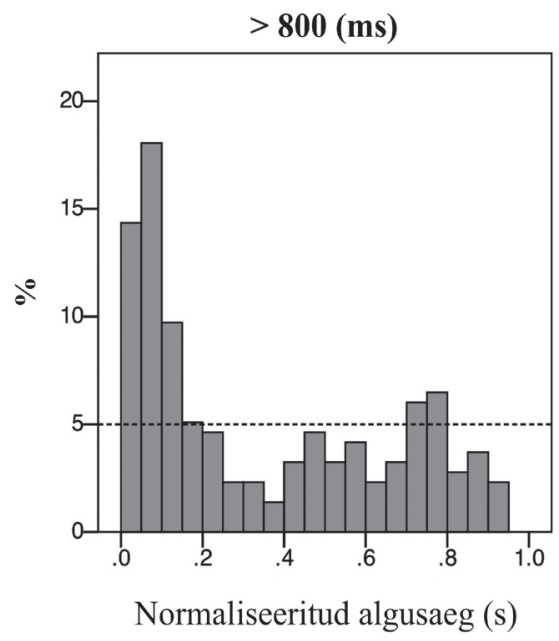

Joonis 3. Lühemate kui $800 \mathrm{~ms}$ ja pikemate kui $800 \mathrm{~ms}$ lausungite jaotumine kõneleja väljahingamisfaasis. Lausungite algusajad on normaliseeritud kõneleja väljahingamisfaasi alguse suhtes.

Analüüsi teises osas keskenduti tagasisidepartiklite esinemisele vestluspartneri hingamistsükli suhtes. Vaadeldud andmestikust enamik $(67,5 \%)$ esines vestluspartneri väljahingamisfaasi jooksul, kusjuures esinemissagedus suurenes seda rohkem, mida lähemale jõudis partneri väljahingamisfaasi lõpp. Ülejäänud, vestluspartneri sissehingamisfaasi jooksul esinevad tagasisidepartiklid näitasid vastupidist mustrit: kõige enam algavad need vahetult pärast sissehingamise algust. Mida kauem oli kestnud partneri sissehingamisfaas, seda vähem produtseeris kuulaja tagasisidepartikleid.
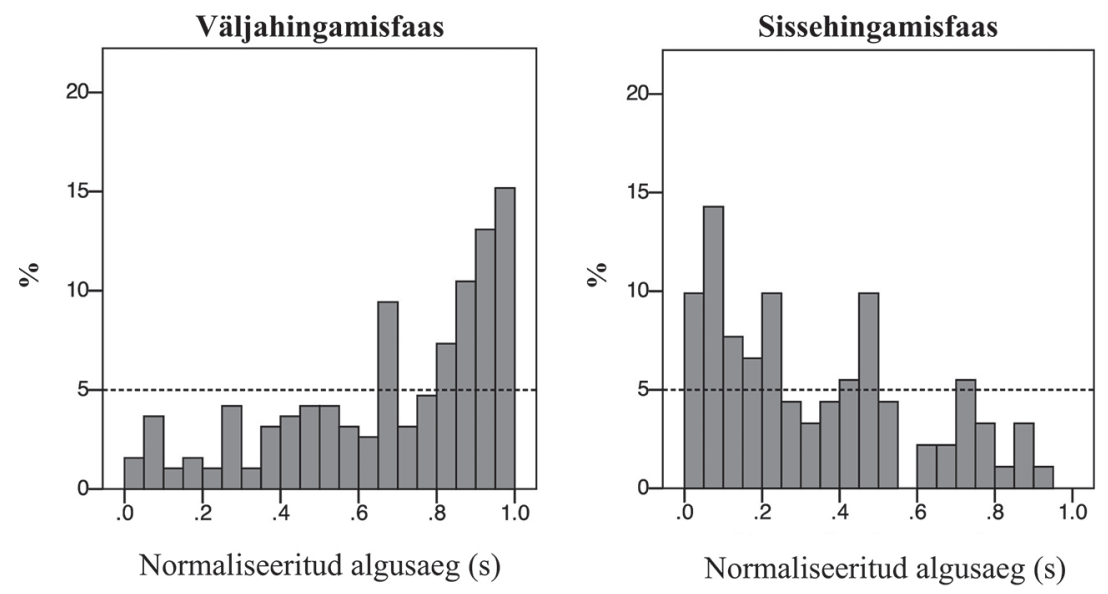

Joonis 4. Tagasisidepartiklite normaliseeritud jaotumine kõneleja välja- ja sissehingamisfaasides. Lausungite algusajad on normaliseeritud kõneleja sisse- ja väljahingamisfaaside algusaegade suhtes, mitte kuulaja tagasisidepartiklite hingamisfaaside suhtes. 
Tulemused näitavad, et tagasisidepartikleid ei erine ülejäänud kõnevoost mitte ainult nende kestuse järgi. Samuti selgus, et tagasisidepartiklid esinevad kõige enam siis, kui vestluspartneri väljahingamisfaas läheb üle sissehingamisfaasiks. Järelikult esineb tagasisidepartikleid spontaansetes vestlustes kõige rohkem siis, kui vestluspartner on oma jutuga lõpule jõudmas või on äsja lõpetanud - väljahingamise lõppedes (sellega koos lõpeb ka jutt) või sissehingamise alguses (jutt on just lõppenud).

\subsection{Eksperiment 2. Hingetõmbe ulatus rääkimise eel}

Järgneva katsega püüti välja selgitada, kas ja kuidas on hingetõmbe sügavus seotud kõnevooru alustamise ja hoidmise kavatsusega nii tagasisidepartiklites kui ka kõnevoorudes. Täpsemalt uuriti, kas kõnevoorule või lausungile vahetult eelnevate ja kõnevoorusiseste hingetõmmete amplituudid erinevad ja kui nii, siis kas see peegeldub hingetõmbe alguses ja lõpus kopsudes oleva õhuhulga erinevas väärtuses. Saadud tulemusi võrreldi tagasisidepartiklitele eelnenud hingetõmmete ulatusega.

Katses kasutati kolme osalejaga spontaansete eestikeelsete vestluste materjali. Analüüsist tuli välja jätta sellised andmed, kus hingamissignaalis oli kõnega samaaegselt näha sissehingamist - see võis juhtuda näiteks mõne suurema liigutuse tõttu, mille rihmad automaatselt registreerisid. Samuti eemaldati andmestikust kõik kõnevoorud, mille algusele eelnes naermine, sest naerdes kasutatakse ära peaaegu kogu õhk mis võimalik ning seetõttu on kõnele eelnev hingetõmme pärast naermist alati väga sügav.

Katse esimeses osas keskenduti sellistele kõnevoorudele, mis koosnesid vähemalt kahest hingetõmberühmast, mille jooksul vestluspartnerid kõnelejale vahele ei seganud. Vahelesegamisena ei mõelda siinjuhul näiteks tagasisidepartikleid, sest neid ei planeerita vestluses ette ning seetõttu ei peeta nende produtseerimist ka kõnevooru haaramiseks (Heldner jt 2013: 137; Włodarczak, Heldner 2015).

Materjalile rakendatud piirangute tõttu vähenes analüüsitavate andmete hulk 50 sobiva kõnevooruni. Ehkki 19 kõnevooru sisaldasid kolme või rohkemat hingetõmmet, oli neid põhjalikuks analüüsiks liiga vähe. Seetõttu jäid vaatluse alla vaid igale kõnevoorule vahetult eelnev hingetõmme ja sama kõnevooru sees olev esimene hingetõmme. Iga katseisiku hingamislaine väärtused normaliseeriti salvestussessioonile eelnenud kalibreerimisel kogutud kõnelejate kopsude miinimum- ja maksimummahtude järgi.

Analüüsi statistiline osa viidi läbi ANOVA testidega programmis $\mathrm{R}(\mathrm{R}$ Core Team 2015), kus sõltumatu muutujana analüüsiti hingetõmbe asukohta ja sõltuvate muutujatena hingetõmbe ulatust ning õhutaseme väärtusi hingetõmbe alguses ja lõpus.

Tulemused näitasid, et kahe hingetõmbe alguses kopsudes oleva õhuhulga väärtuste vahel ei olnud olulist erinevust. Kõnevoorule eelneva ja vooru algusele järgneva hingetõmbe lõpu õhutasemeid võrreldes selgus seevastu, et need erinevad statistiliselt olulisel määral $(p<.05)$. Kõik hingetõmbed algasid seega enam-vähem samalt õhuhulga tasemelt, ent lõppesid oluliselt erinevatel tasemetel (seda illustreerib joonis 5). Hingetõmmete ulatust uurides selgus, et kõnevooru algusele eelneva ja sellele järgneva hingetõmbe sügavus on statistiliselt olulise erinevusega $(p<.005)$. 


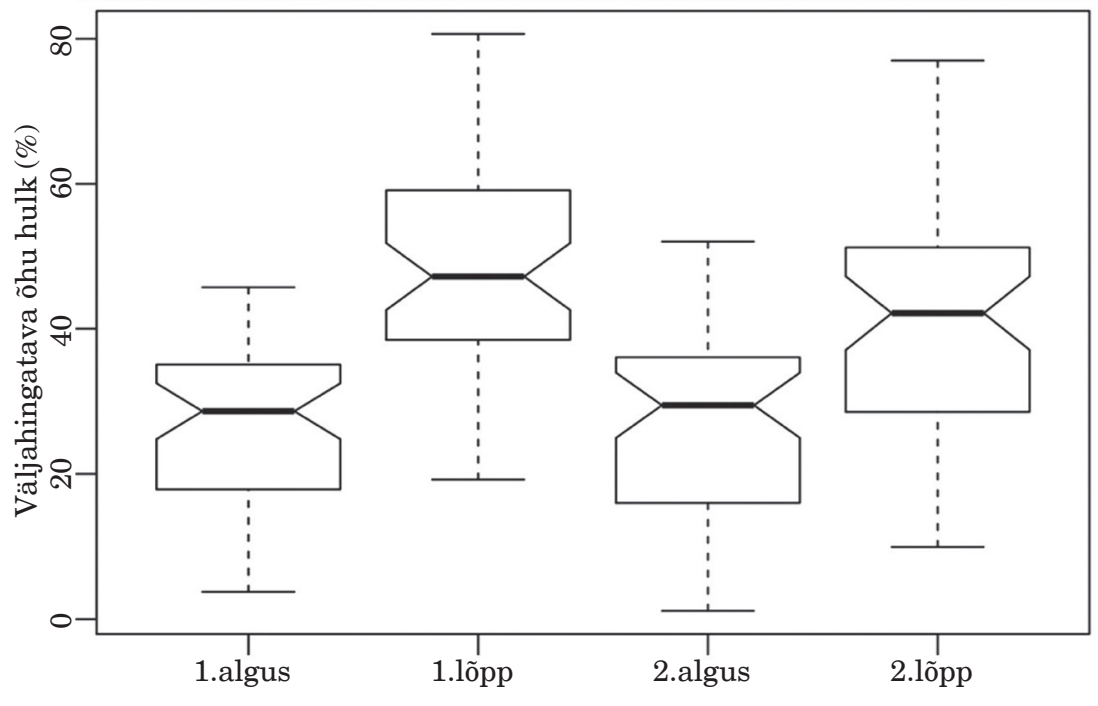

Hingetõmbe algus

J o o n i s 5. Kõnevoorueelse (1.) ja esimese kõnevoorusisese (2.) hingetõmbe alguse ja lõpu õhutaseme normaliseeritud väärtused. Õhuhulga \% tähendab suhtarvu sellest õhuhulgast, mida inimene on võimeline välja hingama (ingl vital capacity, $\mathrm{VC})$.

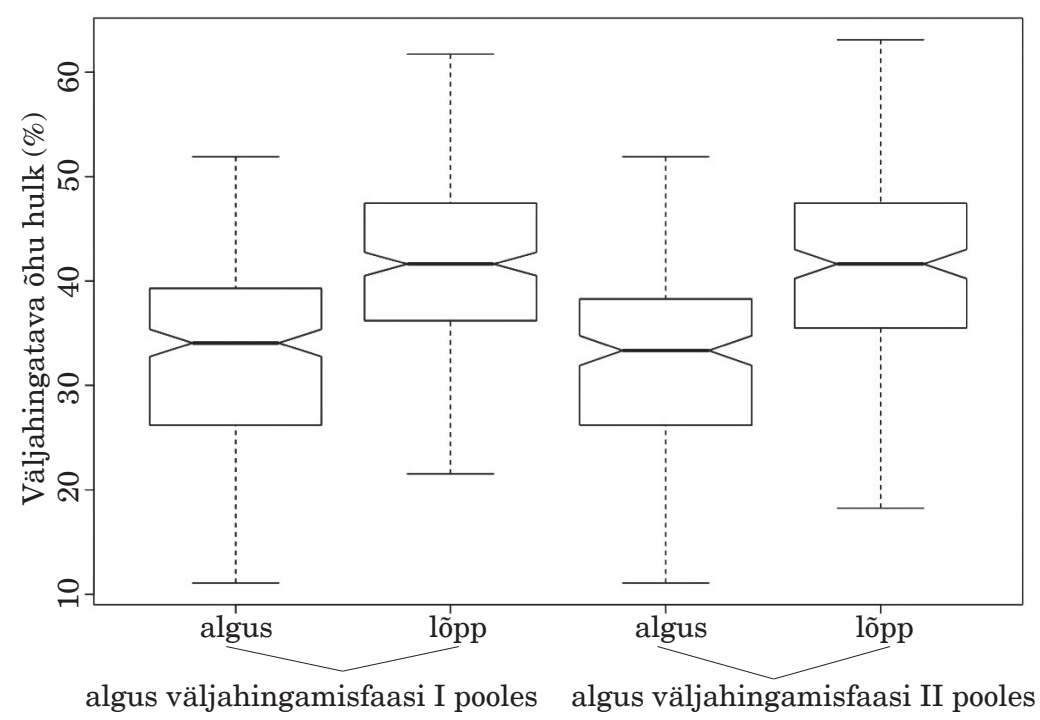

Joonis 6. Tagasisidepartiklitele eelneva hingetõmbe algus- ja lõppväärtused. Hingetõmmete väärtused on normaliseeritud kõneleja kopsude miinimum- ja maksimummahtude järgi. Tagasisidepartiklite algused on normaliseeritud samal ajal toimunud väljahingamisfaasi alguse ja lõpu järgi. 
Katse teises osas keskenduti seevastu tagasisidepartiklitele, mille jaoks kasutati sama andmestiku vestlustes esinenud tagasisidepartikleid, mis olid lühemad kui 800 ms. Ehkki tagasisidepartikleid võib tekitada kogu hingamistsükli vältel, on fookus siin väljahingamisfaasi partiklitel. Eksperimendist 1 selgus, et tagasisidepartiklid algavad enamasti väljahingamisfaasi alguses, aga sageli ka oluliselt hiljem. Seetõttu jaotati tagasisidepartiklid kahte gruppi selle järgi, kus nende algused produtseerija väljahingamisfaasis asusid: esimeses pooles $(N=268)$ ja teises pooles $(N=193)$. Nagu lausungite puhul, vaadeldi ka siin, kui sügav on hingetõmme enne tagasisidepartikli produtseerimist (joonis 6 ).

Tulemused näitavad, et tagasisidepartiklitele eelnenud hingetõmbe ulatus ega algus- ja lõppväärtused ei sõltu sellest, millal need väljahingamisfaasis tekitatakse. Tagasisidepartiklitele eelneva hingetõmbe ulatus on oluliselt väiksem kui kõnevoorude algustele eelnevad hingetõmbed. Samuti on kõnevooru algusele eelneva hingetõmbe lõppväärtus suurem kui tagasisidepartikli algusele eelneva hingetõmbe lõppväärtus.

Kõnelejad alustavad kõiki mõõdetud hingetõmbeid umbes samalt puhkeasendi tasemelt (u 30 \% väljahingatavast kopsumahust), ent hingavad kõnevoorueelse hingetõmbe ajal sisse oluliselt rohkem õhku kui kõnevoorusisese või tagasisidepartiklile eelneva hingetõmbe jooksul. Samas tuleb ära märkida, et keelejuhtidelt oli erinev hulk materjali ning individuaalsed erinevused võivad samuti rolli mängida.

\section{Arutelu}

Artikli fookus oli kahel kõneplaneerimise seisukohalt erineval uurimisobjektil, et uurida spontaansele kõnele iseloomulikke hingamismustreid ja käsitleda täpsemalt kahte vooruvahetuse seisukohalt olulist mehhanismi. Esiteks olid vaatluse all lausungid, mida planeeritakse ette. Täpsemalt olid fookuses nendega kaasnevad hingamismustrid, et uurida, kas lausungitele eelnevad hingetõmbed erinevad kõnevoorude alguses ja sees. Teiseks keskenduti tagasisidepartiklite (nt $m h m h$, jajah, okei) ajastusele hingamistsüklis ja neile eelnenud hingetõmmete sügavusele.

Eksperimendiga 1 püüti välja selgitada, kuidas jaotuvad tagasisidepartiklite asukohad hingamismustris võrreldes muude lausungitega. Nimelt oli tagasisidepartiklite lühiduse ja suhtelise vaiksuse tõttu põhjust arvata, et nende planeerimine erineb muude lausungite planeerimisest, kajastudes ka hingamismustris. Eksperimendiga 2 uuriti, kas ja kuidas on hingetõmmete sügavus seotud kõnevooru alustamise ja hoidmise kavatsustega. Otsiti, kas kõnevoorule vahetult eelneva ja kõnevoorusiseste hingetõmmete ulatused erinevad ja kas see peegeldub hingetõmbe alguses ja lõpus kopsudes oleva õhuhulga erinevas väärtuses. Saadud tulemusi võrreldi tagasisidepartiklitele eelneva hingetõmbe ulatuse ja algus- ning lõppväärtustega.

Esimese eksperimendi eesmärk oli välja selgitada, kas tagasisidepartiklid esinevad hingamismustris vabamalt kui lausungid ja kui nii, siis kas seda põhjustab nende omadus mitte haarata kõnevooru või on see pigem seotud nende lühikese kestusega. Kõigepealt vaadeldi tagasisidepartiklite ja muude lausungite suhtelisi algusaegu nende produtseerija hingamistsüklis. See- 
järel vaadeldi, kuhu asetuvad tagasisidepartiklid vestluspartneri (kõnevooru hoidja) hingamistsükli suhtes, et uurida võimalikke seoseid vestluspartneri käitumisega. Selgus, et lausungi alguspunkti väljahingamisfaasis määrab selle kestus, mitte pragmaatiline funktsioon. Kui produtseeritav kõneüksus on piisavalt lühike, et selle jaoks ei pea õhku juurde hingama, öeldakse see kohe välja. Pikemateks lausungiteks tuleb aga valmistuda ja enne nende produtseerimist kopsude õhuvaru suurendada. Kuna tagasisidepartiklite esinemise määrab kõnelejalt tulev info, ei tea kuulaja täpselt, millal tagasisidepartikleid vestluses produtseerida, ja selleks on keeruline valmistuda.

Oluline on, et tagasisidepartikleid ei ole võimalik muust kõnevoost eristada pelgalt nende lühiduse abil, sest lühikesed lausungid, mis ei ole tagasisidepartiklid, käitusid väljahingamisfaasi suhtes tagasisidepartiklitega väga sarnaselt. Pikemad lausungid seevastu algavad enamasti vahetult pärast väljahingamisfaasi algust. Tagasisidepartiklite esinemine vestluspartnerite hingamistsükli suhtes näitas, et tagasisidepartiklite asukoht peegeldab nende funktsiooni kinnitada uue informatsiooni vastuvõttu ja infovoo jälgimist. Noogutuste asukohta hingamistsüklis uurides on Włodarczak jt (2015) sama tulemuse kinnituseks leidnud, et noogutused toimuvad samuti väljahingamis- ja sissehingamisfaasi piiril, kui kõneleja on oma jutuga lõpule jõudmas/jõudnud ja tagasisidepartikli andmine muutub relevantseks. Järelikult on võimalik, et kui tagasisidepartikli väljaütlemiseks on kopsudes liiga vähe õhku, asendatakse see noogutusega (Włodarczak jt 2015).

Teisest eksperimendist selgus, et sügav hingetõmme on tõenäoliselt suhtlemiseesmärki täitev märguanne - nii püütakse näidata, et osalejal on soov haarata kõnevoor. Ehkki sügav hingetõmme võib tähendada ükskõik kui madalalt õhusisalduse tasemelt alustatud suuremahulist hingetõmmet, algavad hingetõmbed kõnealustes katsetes kopsude puhkeasendist. Puhkeasendist allapoole sattumine on füüsiliselt ebamugav ja üldjuhul välditakse olukordi, kus kopsudes õhku nii väheks jääb. See seletab, miks suurem osa hingetõmbeid algas kopsude puhkeasendi tasemelt, mitte oluliselt madalamalt ega kõrgemalt tasemelt. Kopsude täitumisega venib ka rindkere - see on füüsiliselt märgatav ja saadab vestluspartneritele kiiresti vajaliku signaali selle kohta, et kaasvestleja on valmis rääkima hakkama. Niisiis on võimalik, et hingetõmbe ulatus üksi pole kõnevooru haaramiseks määrav, vaid kopsude õhutase hingetõmbe lõpus võib vestluse kulgu tugevamalt mõjutada.

Eelnevatest uurimustest on selgunud, et hingetõmbe sügavus korreleerub positiivselt ka järgneva lausungi pikkusega (Rochet-Capellan, Fuchs 2013). Seega on tõenäoline, et sügavam hingetõmme peegeldab pikema kõnevooru kavatsust, mis võib sisaldada mitut hingetõmmet ja lühemat kõneüksust. Kui kõnevooru alustaja annab märku (nt silmside, hingetõmbe vm abil), et tal on kavatsus edasi rääkida, võib see vähendada vestluspartnerite vahelesegamiskatsete hulka sel ajal, kui kõneleja peab tegema lühikese hingetõmbepausi. Samal ajal on võimalik, et need lühikesed hingetõmbepausid - kõnevoorusisesed madalama amplituudi ja madalama õhuhulga lõppväärtusega hingetõmbed - toimivad kui fraseerimisvahendid. Nende abil tükeldatakse kõne sobiva kestusega loogilisteks üksusteks, hõlbustades kõnest arusaamist ja selle produtseerimist.

On veel hulk lisategureid, mis võivad mängida vooruvahetussüsteemi ja hingamise vahekorras suurt rolli. Näiteks on võimalik, et kiiremad hinge- 
tõmbed nõuavad suuremat õhuvoogu, mis omakorda võib tõsta hingamismüra taset. Hingamismüra võib samuti olla oluline faktor lausungite piiride paigutamisel ning toimida samal ajal vooruhoidmisvahendina.

\section{Lõpetuseks}

Artikli peamine eesmärk oli kirjeldada kõneplaneerimise seisukohalt kahte erinevat uurimisobjekti, et näidata, kuidas need hingamismustris väljenduvad. Vaatluse all olid seetõttu nii vooruvahetust reguleerivad vahendid hingamismustris, mida üldjuhul planeeritakse vestlustes ette, kui ka tagasisidepartiklid, mida ei saa samamoodi ette planeerida.

Eksperimentide tulemused viitavad võimalusele, et erinevus kõnevoorudele ja tagasisidepartiklitele eelnevate hingetõmmete ulatuses ja lõppväärtustes on funktsionaalne ning seotud kõneüksuse kestusega. Eksperiment 1 näitas, et tagasisidepartiklid on väljahingamisfaasis ühtlasemalt jaotunud kui lausungid, mis algavad enamasti vahetult pärast hingetõmbe lõppu. Tagasisidepartiklid on tavaliselt vaiksed ja lühikesed, niisiis ei nõua nende tekitamine suurt õhuhulka või spetsiaalset valmistumist hingetõmbe kujul. Tagasisidepartikli saab suure tõenäosusega produtseerida olemasoleva õhuhulga abil just siis, kui see vestluspartneri kõne suhtes oluliseks muutub. Eksperiment 2 näitas, et tagasisidepartiklite eel on hingetõmbed väiksema ulatusega kui kõnevoorude eel. Järelikult põhjustab tagasisidepartiklite ja lühikeste lausungite võrdsemat jaotumist hingamistsüklis vähene õhuvajadus nende tekitamiseks. Seetõttu pole võimalik tagasisidepartikleid kõnevoos identifitseerida kestuse järgi, sest lühemad lausungid käituvad hingamistsükli suhtes väga sarnaselt. Lausungitele eelnevate hingetõmmete parameetrite analüüs viitab aga, et lausungitele eelnevate hingetõmmete lõppväärtus on tõenäoliselt peale lausungiks valmistumise ka suhtlemiseesmärki täitev märguanne - sellega püütakse näidata, et osalejal on soov haarata kõnevoor.

\section{Kirjandus}

Aare, Kätlin, Włodarczak, Marcin, Heldner, Mattias 2014. Backchannels and breathing. - Proceedings from FONETIK 2014. Toim M. Heldner. Stockholm: US-AB, lk 47-52.

A a re, Kätlin, Włod a r c zak, Marcin, Held ner, Mattias 2015. Inhalation amplitude and turn-taking in spontaneous Estonian conversations. - Proceedings from FONETIK 2015, June 8-10. Toim Malin Svensson Lundmark, Gilbert Ambrazaitis, Joost van de Weijer. Lund: Lund University, lk 1-5.

ADInstruments. LabChart software and PowerLab hardware. Version 8. [Arvutiprogramm.] New South Wales: ADInstruments, 2014.

Boersma, Paul, Weenink, David 2015. Praat: doing phonetics by computer. Version 5.3.84. [Arvutiprogramm.] http://www.praat.org

B u s ch m ei er, Hendrik, Wł od a r c z a k, Marcin 2013. TextGridTools: A TextGrid Processing and Analysis Toolkit for Python. - Tagungsband der 24. Konferenz zur elektronischen Sprachsignalverarbeitung (ESSV 2013). Toim P. Wagner. Dresden: TUDpress, lk 152-157. 
Butterw orth, Brian 1975. Hesitation and semantic planning in speech. - Journal of Psycholinguistic Research, kd 4, nr 1, lk 75-87.

Clark, John W., Yallop, Collin, Fletcher, Janet 2007. An Introduction to Phonetics and Phonology. 3rd ed. (Blackwell Textbooks in Linguistics.) Oxford: Blackwell Publishing.

Conrad, B., Schönle, P. 1979. Speech and respiration. - Archiv für Psychiatrie und Nervenkrankheiten, kd 226, nr 4, lk 251-268.

Con rad, B., Thal acker, S., Schönle, P. 1983. Speech respiration as an indicator of integrative contextual processing. - Folia Phoniatrica, kd 35, nr 5, lk 220225.

Couper-Kuhlen, Elizabeth, Selting, Margret (toim) 1996. Prosody in Conversation: Interactional Studies. Cambridge-New York: Cambridge University Press.

Cruttenden, Alan 1986. Intonation. Cambridge: Cambridge University Press.

Edlund, Jens, Heldner, Mattias, Włod arczak, Marcin 2014. Catching wind of multiparty conversation. - Proceedings of the LREC2014 workshop on Multimodal Corpora: Combining Applied and Basic Research Targets. Toim J. Edlund, Dirk Heylen, Patrizia Paggio. Reykjavík, lk 35-36.

Euler, C. von 1982. Some aspects of speech breathing physiology. - Speech Motor Control. Toim Sten E. Grillner, Björn Lindblom, James Lubker, Anders Persson. New York: Pergamon Press, lk 93-103.

Feldstein, Stanley 1973. Temporal patterns of dialogue: Basic research and reconsiderations. - Studies in Dyadic Communication. Toim Aron Wolfe Siegman, Benjamin Pope. New York: Pergamon Press, lk 91-113.

Ferreir a, Fernanda, Swets, Benjamin 2002. How incremental is language production? Evidence from the production of utterances requiring the computation of arithmetic sums. - Journal of Memory and Language, kd 46, nr 1, lk 57-84.

French, Peter, Local, John 1983. Turn-competitive incomings. - Journal of Pragmatics, kd 7, nr 1, lk 17-38.

Fu ch s, Susanne, Petro ne, Caterina, Krivok a pi ć, Jelena, Ho ole, Philip 2013. Acoustic and respiratory evidence for utterance planning in German. - Journal of Phonetics, kd 41, nr 1, lk 29-47.

G a r d n e r, Rod 2001. When Listeners Talk: Response Tokens and Listener Stance. Amsterdam: J. Benjamins Publishing.

Grosjean, François, Collins, Maryann 1979. Breathing, pausing and reading. - Phonetica, nr 36, lk 98-114.

G u m per z, John J. 1982. Discourse Strategies. Cambridge: Cambridge University Press.

Heldner, Mattias, Hjalmarsson, Anna, Edlund, Jens 2013. Backchannel relevance spaces. - Nordic Prosody: Proceedings of the XI ${ }^{\text {th }}$ Conference, Tartu 2012. Toim Eva Liina Asu, Pärtel Lippus. Frankfurt am Main: Peter Lang, lk 137-146.

Hix o n, Thomas J. 1982. Speech breathing kinematics and mechanism inferences therefrom. - Speech Motor Control. Toim Sten E. Grillner, Björn Lindblom, James Lubker, Anders Persson. New York: Pergamon Press, lk 75-93.

Hix o n, Thomas J. 1987. Respiratory function in speech. - T. J. Hixon, Respiratory Function in Speech and Song. London: Taylor \& Francis Ltd., lk 1-54.

Hixon, Thomas J., Goldman, Michael D., Mead, Jere 1973. Kinematics of the chest wall during speech production: volume displacements of the rib cage, 
abdomen, and lung. - Journal of Speech and Hearing Research, kd 16, nr 1, lk 78-115.

Hu ber, Jessica E. 2008. Effects of utterance length and vocal loudness on speech breathing in older adults. - Respiratory Physiology \& Neurobiology, kd 164, nr $3,1 \mathrm{k} 323-330$.

Is hi i, Ryo, Otsuka, Kazuhiro, Ku m a n o, Shiro, Y a m at o, Junji 2014. Analysis of respiration for prediction of who will be next speaker and when in multi-party meetings. - Proceedings of the $16^{\text {th }}$ International Conference on Multimodal Interaction (ICMI '14), lk 18-25.

Jaffe, Joseph, Feldstein, Stanley 1970. Rhythms of Dialogue. New York: Academic Press.

Jones, R. L., Nzekwu, M. M. U. 2006. The effects of body mass index on lung volumes. - Chest, kd 130, nr 3, lk 827-833.

Konno, K., Mead J. 1967. Measurement of the separate volume changes of rib cage and abdomen during breathing. - Journal of Applied Physiology, kd 22, nr 3 , lk 407-422.

Krivokapić, Jelena 2010. Speech planning and prosodic phrase length. - Proceedings of the 5th International Conference of Speech Prosody. Chicago, lk 1-4, artikkel nr 311.

L evelt, Willem J. M. 1989. Speaking: From Intention to Articulation. Cambridge: MIT Press.

Li e b e r m a n, Philip 1967. Intonation, Perception and Language. Cambridge: MIT Press.

M c F arland, David H. 2001. Respiratory markers of conversational interaction. - Journal of Speech, Language, and Hearing Research, kd 44, nr 2, lk 128-143.

McKay, L. C., Evans, K. C., Frackowiak, S. J., Corfield, D. R. 2003. Neural correlates of voluntary breathing in humans. - Journal of Applied Physiology, kd 95, nr 3, lk 1170-1178.

$\mathrm{R}$ Core Team 2015. R: A language and environment for statistical computing. $\mathrm{R}$ Foundation for Statistical Computing, Vienna, Austria. [Arvutiprogramm.] http://www.R-project.com

Rochet-Capellan, Amélie, Fuchs, Susanne 2013. The interplay of linguistic structure and breathing in German spontaneous speech. - Proceedings of INTERSPEECH 2013. 14 ${ }^{\text {th }}$ Annual Conference of the International Speech Communication Association, August 25-29. Lyon, lk 1128-1132.

Rochet-Capellan, Amélie, Fuchs, Susanne 2014. Take a breath and take the turn: how breathing meets turns in spontaneous dialogue. - Philosophical Transactions of the Royal Society B: Biological Sciences, kd 369, nr 20130399.

Schegloff, Emanuel A. 1996. Turn organization: One intersection of grammar and interaction. - Interaction and Grammar. Toim Elinor Ochs, E. A. Schegloff, Sandra A. Thompson. Cambridge: Cambridge University Press, lk 52-133.

W ang, Yu-Tsai, Green, Jordan R., Nip, Ignatius S. B., Kent, Ray D., Kent, Jane Finley 2010. Breath group analysis for reading and spontaneous speech in healthy adults. - Folia Phoniatrica et Logopaedica, kd 62, nr 6, lk 297-302.

Wats on, H. 1980. The technology of respiratory inductive plethysmography. Proceedings of the Second International Symposium on Ambulatory Monitoring (ISAM 1979). Toim F. D. Stott, E. B. Raftery, L. Goulding. London: Academic Press, lk 537-556.

Whalen, D. H., Kin sell a -Sh aw, J. M. 1997. Exploring the relationship of inspiration duration to utterance duration. - Phonetica, kd 54, nr 3-4, lk 138-152. 
Wheeldon, Linda, Lahiri, Aditi 1997. Prosodic units in speech production. Journal of Memory and Language, kd 37, nr 3, lk 356-381.

Winkw orth, Alison L., Davis, Pamela J., Ad a ms, Roger D., Ellis, Elizabeth 1995. Breathing patterns during spontaneous speech. - Journal of Speech, Language, and Hearing Research, kd 38, nr 2, lk 124-144.

Włodarczak, Marcin, Heldner, Mattias 2015. Respiratory properties of backchannels in spontaneous multiparty conversation. - ICPhS Proceedings 18. Glasgow: University of Glasgow.

Wło d a r c z a k, Marcin, H eld ner, Mattias, Ed l u nd, Jens 2015. Communicative needs and respiratory constraints. - Proceedings of INTERSPEECH 2015. 16th Annual Conference of the International Speech Communication Association, September 6-10. Dresden, lk 3051-3055.

Wray, Alison, Perkins, Michael R. 2000. The functions of formulaic language: an integrated model. - Language \& Communication, kd 20, nr 1, lk 1-28.

Yngve, Victor H. 1970. On getting a word in edgewise. - Papers from the sixth regional meeting of the Chicago Linguistic Society. Chicago: Chicago Linguistic Society, lk 567-578.

\section{Conversational intentions as reflected in the breathing pattern}

Keywords: phonetics, spontaneous speech, speech breathing, speech planning, turn taking, backchannels

The main aim of this article was to describe how two functionally different objects in terms of speech planning behave in the respiratory patterns of spontaneous speech. First, the focus was on the timing of utterances and backchannels (short feedback items signalling that the listener understands and follows the speaker) in the respiratory cycle. The second focus was on the parametres of the inhalations preceding utterances and backchannels. The article is an overview of research done in speech breathing using data from spontaneous Estonian conversations.

The data is made up of spontaneous dialogues and multiparty conversations held in Estonian and recorded at Stockholm University in 2014 and 2015. Each conversation lasted from 20-30 minutes and was recorded in high quality audio and video. Respiratory data from each participant was collected and recorded using respiratory inductance plethysmography.

The results indicate that the difference in the parametres of inhalations preceding utterances and backchannels is functionally motivated and connected to the duration of the speech units. Experiment 1 showed that the starting points of backchannels are more evenly distributed in the breathing cycle than the starting points of utterances. However, utterances as short as the majority of backchannels behave similarly and therefore backchannels cannot be distinguished in the speech flow based on their durational properties alone. Experiment 2 demonstrated that inhalations preceding utterances are considerably larger than those preceding backchannels. Backchannels are usually short and quiet, they can be produced whenever they become relevant in the course of the conversation, and as such are not produced as an attempt to take over the conversational floor. Therefore, they do not need to be planned in the same way as utterances. In addition, the amount of air in the lungs at the end of an inhalation preceding an utterance can function as a sign of taking over the floor.

Kätlin Aare (b. 1991), MA, Universiy of Tartu,PhD Student, katlin.aare@ut.ee 